\title{
Job Market Research Analysis of Material Forming \& Control Engineering Specialty for Breakthrough Cultivation
}

\author{
Jitao $\mathrm{Du}^{1, \mathrm{a}}$ \\ ${ }^{1}$ Advanced Vocational Technical College ,Shanghai University of Engineering Science \\ Hongkou, Shanghai, China \\ adjtjaster@126.com
}

\begin{abstract}
Material forming industry urgently needs high-quality engineering and technical skill talents with practical operation ability and using all kinds of digital tools for the independent Die \& Mould design and manufacture. The paper analyzes the material forming industry situation , development trend and current situation of Shanghai mould talents demand and training, the results showed that people possessing more than one post, fusing multidisciplinary knowledge, mastering multi-capacity, realizing the future development demand exceeds supply. All of these provide the support for the breakthrough cultivationin of the professional positioning and the talent cultivation aim determining.
\end{abstract}

Keywords: Material Forming \& Control Engineering, the breakthrough cultivation, Technical skills compound

\section{材料成型及控制工程专业中本贯通培养人才市场调研分析}

\author{
杜继涛 $1, a$ \\ ${ }^{1}$ 上海工程技术大学高等职业技术学院, 虹口, 上海, 中国 \\ djtjaster@126.com
}

\begin{abstract}
摘要. 材料成型行业一线急需具有实践操 作能力, 又能够运用各种数字化工具独立进 行模具设计和制造的高素质工程、技术技能 复合型人才。为此组成了调研团队, 分析了 材料成型行业现状及发展趋势和上海模具 人才需求和培养现状，得出具备一人多岗、 融合多领域知识、一人多能、着眼未来发展 的技术、技能型人才供应严重不足，这为该 专业的中本贯通专业定位和人才培养目标 确定提供了支持。
\end{abstract}

关键词:材料成型控制工程; 中本贯通; 技 术技能复合型

\section{1. 引言}

对制造业从业人员而言, 以往大规模的 工业化生产背景下的专业分工日趋融合, 要 求岗位能力从单一走向复合, 生产技术不断 更新要求生产技术人员自身具有再学习与 再发展能力, 需要掌握设计、跟踪和控制制 造工艺流程的生产技能，不断改进工艺、优 化设计及开发能力 $[1]$ 。

材料、能源、信息是构成社会文明和国 民经济的三大支柱, 其中材料是科学技术发 展的物质基础, 材料加工是材料具体应用的 重要手段, 它和制造业紧密相连。模具作为 材料成形的重要工装, 有 “工业之母” 的称 
号。然而当前模具行业面临产业结构调整与 技术升级, 现代模具成形技术对传统模具设 计、模具制造等岗位能力提出了新的需求。 因此, 模具行业一线急需能了解与应用新技 术、新工艺, 既具有实践操作能力, 又能够 运用各种数字化工具独立进行模具设计和 制造的高素质工程、技术技能复合型人才。

《上海市中长期教育改革和发展规划 纲要（2010～2020年）》指出 “让学生成 为适应工作变化的知识型、发展型技能人 才。促进中等职业教育与高等职业教育衔 接, 构建中等职业教育与高等职业教育课 程、培养模式和学制贯通的 “立交桥” , 打 通技能型人才深造发展渠道, 为学生的多元 发展提供保障。” “中本贯通” 是其中具有 创新性与革命性的人才培养方式变革。

为贯彻国家和上海市中长期教育改革 和发展规划纲要及上海市教委促进中等职 业教育与高等教育有机衔接的要求, 加快培 养适应区域经济社会发展需要的面向先进 制造业的知识型、发展型技术技能应用型人 才。上海工程技术大学与上海市高级技工学 校为了适应上海产业调整及升级对高素质 工程、技术技能复合型人才的需求, 经过研 究决定选择《材料成型及控制工程 (现代模 具成形技术）》专业作为中本贯通 “ $3+4$ ” 培养模式试点。为此组成了调研团队, 通过 典型模具企业实地走访、行业协会咨询、人 才招聘网企业岗位需求分析等手段开展了 研究和分析。

\section{2 材料成型（模具）行业现状及发展趋势}

\section{1材料成型（模具）行业现状}

当今世界, 科技创新日新月异, 信息化、 现代化、全球化发展势不可挡, 新兴发展中 国家快速崛起, 国际经济和制造产业格局正 面临新的大发展、大调整、大变革。制造业 是国民经济的主要支柱, 模具广泛应用于电 子、汽车、电机、电器、仪表、家电和通讯 等产品的制造, 如汽车零部件的 $95 \%$ 、家电 零部件的 $90 \%$ 为模具制件, IT 等消费电 子、电器、包装品等诸多产业当中的 $80 \%$ 的 零部件都是由模具孕育出来的, 模具对我国 经济发展、国防现代化和高端技术服务起到
了非常重要的支撑作用。在绿色制造的今 天, 模具在替代电镀喷漆等传统工艺, 以塑 代木、以塑代金属实现轻量化等制造领域也 发挥着重要的作用。据国外统计资料, 模具 可带动其相关产业的比例大约是 $1: 100$, 即 模具发展 1 亿元, 可带动相关产业100亿元。 模具技术水平的高低, 在很大程度上决定着 产品的质量、效益和新产品的开发能力。因 此, 模具已成为衡量一个国家产品制造水平 高低的重要标志[1][2]。

我国正成为世界模具大国, 目前我国的 模具总产值已跃居世界第三, 仅次于日本和 美国。根据中国模具行业发展报告, 2012 2020 年中国模具产值将从2012年的 1600 亿 元增长至2020年的7000亿元, 如图1所示, 模具行业市场潜力巨大。

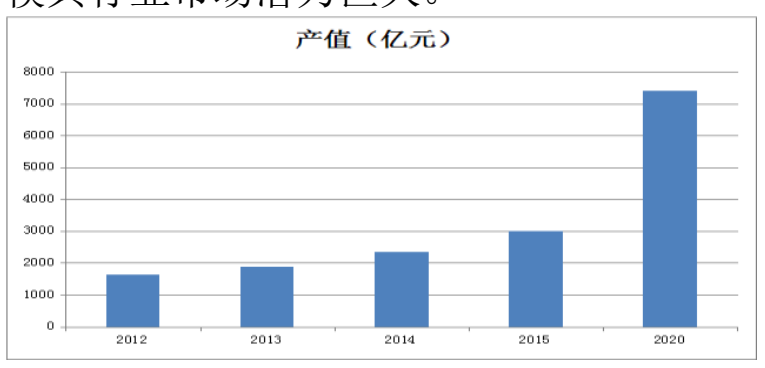

图1 2012 - 2020年模具产值前景预测

目前我国模具产能已超过2000亿元, 已 发展成为世界模具生产大国, 但与世界先进 水平相比, 无论是技术、工艺、管理、产品 水平还是生产方式及服务理念等方面, 仍存 在明显差距，与美国、德国、日本等工业发 达国家相比, 我国模具工业总体水平还相对 落后 10 年以上。

\section{2上海模具行业的现状及发展趋势}

上海模具行业有深厚的基础, 改革开放 后，作为我国经济、金融、信息、贸易及先 进制造业中心之一的上海经济发展突飞猛 进, 上海的模具行业也进入快速发展阶段。 随着众多世界著名企业进驻上海以及民营 企业的发展壮大, 推动了上海模具技术水平 不断提高、制造实力的不断加强、国际竞争 力持续增加, 每年以 $20 \%$ 的增长速度在发 展。截止2013年底, 上海已有一定规模的模 具及相关企业 3000 余家, 从业人员 10 万人 （其中工程技术人员 4 万余人、熟练技术工 人 6 万余人），年产值超过 200 亿元人民币， 上海模具行业的发展特点：（1）模具设计、 
制造能力、企业市场竞争能力较强;

加工设备设施先进；（3）模具企业的高新 技术应用广泛且深入。

国民经济结构调整将使新兴产业和服 务业加速发展, 高新技术产品将以比以往更 快的速度和更大的广度全面推进, 模具行业 的发展必须与之相适应。模具行业采用数字 化制造技术已有多年, 并已取得了丰硕的成 果[4]。模具企业不但可以为制造业智能化 服务, 而且其本身也逐渐朝着智能化方向发 展。大型、精密、高效、高性能模具在模具 总量中的占比会持续上升, 并不断拓展其用 途与功能, 不断提高其附加值和可靠性。

\section{3 上海模具行业面临技术应用型人才短缺}

近年来, 我国模具行业迅速发展的同 时, 模具中高级人才出现大面积断层, 上海 模具行业也同样面临着这样的问题。加强人 才培养是教育的责任, 人才缺乏已是模具行 业发展的一个大问题。造成这样的局面主要 有两方面的原因: 一是模具下游行业的高速 发展, 使得部分模具行业人才去 “支援” 零 件成形行业; 二是模具行业的快速膨胀分化 不能匹配协调发展, 规模扩张速度大于人才 培养速度, 而模具行业需要具备专业技术和 专业技能的高素质人才, 培养能独挡一面的 技术或技能人才至少需要 3 年的时间, 而培 养一名高素质模具技术技能人才则需要更 长的时间。模具要不断提高水平适应其发 展, 必须要有创新型、复合型人才和高技术 技能人才匹配。

\section{3 模具设计与制造行业人才需求分析}

\section{1上海模具行业调研}

根据上海模具行业协会所作的分析报 告, 目前上海模具人才需求旺盛的重点行业 主要在上海支柱产业、新型产业、装配产业 和战略产业, 主要涉及汽车制造行业、精密 仪器仪表行业、医疗器械、轨道交通行业、 军工行业、IT接插件行业、电子信息、光学 等[1]。

\section{2 上海模具企业调研}

处于产品产业链上游模具企业如上海 大众汽车股份有限公司、上海汇众汽车股份
有限公司, 主要以整套产品为核心, 注重模 具的使用和维修, 注重生产过程的稳定性, 对人才的要求主要是熟悉模具制造流程、能 解决生产现场质量问题的维修装调师; 处于 产品产业链下游模具企业如新兴企业、新建 模具, 主要以配套附件为重点, 注重模具的 制造和设计, 需要大量熟练操作数控设备的 技能型人才和一定的技术人才。对已发展到 一定阶段, 为上游企业一级供应商的模具企 业处于产业链的中间, 它既要为上游企业提 供优质模具, 还要为上游企业提供一定的相 关产品, 更要兼顾下游模具的生产。因此这 类模具企业是行业的核心, 它对有一定实践 经验的技术技能复合型人才需求最旺。

\section{3模具技术应用人才市场需求调研}

当前, 上海模具行业的构成情况大致 是：国有企业6\%，民营企业56\%，三资企 业38\%，民营和三资企业已成为上海模具行 业的主力, 三类企业对人才能力要求如表 1 所示。国有企业管理架构比较完善, 对模具 人才安排和需求根据学历和能力按研发、工 艺编程、操作、维修等方面进行明确分工。 而对于占模具行业总数的 $56 \%$ 的小型民营 企业, 人员比较精干, 各技术岗位人员数量 不太多, 更加注重能力而非学历的全才, 既 精通模具加工工艺、设计, 又能熟练操作模 具设备, 同时对模具的维护维修有一定基础 的复合型的模具人才。外资企业则主要立足 于高精尖产品, 尤其在汽车零件制造及IT 行业, 从而也带动了大量精密模具的制作与 诞生, 由于工作岗位分工较细, 其用人的特 点是能力和学历并重, 知识面广、沟通能力 强, 有一定的可塑性的专才。

\section{4岗位人才来源及要求分析}

随着上海市经济发展目标的提升, 各用 人单位对现代模具成形技术技能人才的职 业迁移和能力要求也在逐步提升。同时用工 成本的增加、未来自动化技术的普遍使用、 岗位融合必然成为一种趋势, 相应的人才需 求也向综合化、全能型发展, 因此, 培养基 础理论扎实, 会操作懂工艺, 又能设计和制 造的人才是首选 [2][5]。然而, 现有普通本 科毕业生的能力结构与企业岗位需求不完 全匹配，特别是融合技能、工艺、设计与一 
体, 解决生产现场问题能力不足, 因此, 生 产现场一线急需能快速响应市场需求的高 素质技术技能复合型人才。

\section{4. 上海模具人才培养分析}

上海现有一所中职学校一一上海工业 技术学校, 每年培养技能型模具人才 50 人; 高职院校现开展模具专业教学学校 2 所: 上 海第二工业大学每年培养 40 人, 上海工程技 术大学每年培养 80 人, 高职模具人才总数 120 人; 上海开展材料成型与控制本科院校 (应用型) 有5所：上海理工大学每年培养 70 人, 上海第二工业大学每年培养 40 人, 上 海电机学院每年培养 70 人, 上海应用技术大 学每年培养 40 人, 上海工程技术大学每年培 养 190 人 (有 60 人偏向电子封装, 60 人 CADCAM), 华东理工大学每年培养 70 人, 合计 480 人。

根据上海市每年需要 3000 模具人才的 规模, 结合上海模具人才供应状况, 约占 $70 \%$ 的技能型模具人才急需, 约占 $5 \%$ 工程 应用人才过剩, 而需要较长周期训练约占 $70 \%$ 的技术技能型人才本地培养明显不足, 这严重影响着处于产业链中游模具企业的 正常生产。技能型短缺严重, 可以通过社会 培训机构短期训练达到, 但基础仍不扎实, 变通性缺乏, 严重影响模具的制造、装配质 量, 进而影响产业链下游企业的模具质量。 工程应用型人才市场需求小于供应, 导致就 业困难。处于产业链中游的技术技能复合型 人才, 社会需求较大, 学校培养无法满足, 虽然可以通过部分具有3 5年实践经验的优 秀高职学生补充, 但仍然存在较大缺口, 短 期培训无法实现, 市场只有通过高薪挖人的 策略。因此, 如何填补这一缺口, 就成了培 养单位急需解决的课题。

\section{5. 结束语}

综合分析上海模具行业的发展现状和 未来趋势, 以及该领域人才供应状况, 基于 产业结构调整与技术升级需要, 可以得出: 技术、技能型人才目前供应严重不足, 而具 备下列能力和知识的高素质技术技能复合 型人才将是目前及未来的人才培养的核心。
（1）一人多岗: 上海 3000 余家模具企 业、特别是产业链中游模具急需融合模具设 计师、模具制造工艺师、模具装调师、生产 现场管理于一体的高素质技术技能复合型 人才。

(2) 融合多领域知识: 要求具有较扎 实的机械专业知识、模具材料及热处理知 识、模具制造工艺知识、冲压工艺和塑料成 型工艺知识、先进材料及成型技术等。

(3) 一人多能: 强调技能一一会操作 数控设备如数控铣床、加工中心等, 会操作 注塑机和压力机, 能装配和调试模具; 懂技 术一一熟悉制造工艺、成型工艺, 能设计冲 压模具和塑料成型模具等; 能指导一一指导 模具钳工高质量装配和修研调试模具, 缩短 模具生产周期, 为上游企业提供优质模具和 产品。

（4）专业对接地方产业: 围绕汽车和 信息产业, 以汽车覆盖件冲压成形技术、多 工位级进模具技术、精密注塑技术为核心, 开展模压一体、模塑一体、模夹一体等培养, 提升零件成形整体解决方案和工程服务等 能力。

（5）着眼未来发展: 智能化是未来的 趋势, 数字化是智能化的基础, 材料成形 $\mathrm{CAE}$ 分析、工装模具 $\mathrm{CAD}$ 及数字化加工以 及多领域集成是一个重点。自动化、绿色制 造是未来模具行业的发展趋势, 因此能运用 先进技术装备、手脑并用, 了解成形自动化 (机械手) 和节能环保的人才是未来的趋 势。

当前上海模具行业高素质技术技能型 人才严重不足, 各类学校培养的人才达成目 标对比如表4所示, 还不能完全适应上海转 型时期, 企业对岗位人才的 5 个方面迫切需 求。而基于应用技术型本科的中本贯通模 式, 采用3年制中职（磨练技能、注重基础） +4 年制本科（强化技能、注重专业知识、 着眼未来发展) 培养则更能满足这一迫切需 求。上海工程技术大学与上海市高级技工学 校选择中本贯通试点专业一一材料成型及 控制工程（现代模具成形技术），正是瞄准 目前模具产业对高素质技术技能人才的需 求而提出。 
综上所述, 在人才需求和供给调研数据 分析基础上, 从上海工程技术大学和上海市 高级技工学校的办学思想、定位及专业特色 出发, 确定 “材料成型及控制工程 (现代模 具成形技术) ”专业作为中本贯通试点。专 业定位和培养目标为: 培养适应区域经济与 社会发展需要, 面向先进制造业模具领域, 具备模具成形技术理论基础, 形成较强计算 机辅助模具及其制造工艺设计能力, 掌握扎 实数字化加工实践技能, 能解决生产现场复 杂、综合性问题的高素质工程、技术技能复 合型人才。就业岗位: 面向模具领域生产一 线, 熟练掌握数字化加工实践技能、系统应 用 CAD/CAM技术的模具制造工艺师或模 具设计师, 以及能综合解决生产一线问题的 现场工程师等; 也可从事模具生产管理, 以 及模具相关应用领域的技术研发、技术服务 与技术支持等工作。

\section{致谢}

本文获得上海工程技术大学教研项目 No. A-2512-10-1308和No. A1-0601-15-0175 支持。

\section{References}

[1] ZHU Heng-rong. Research on Application-oriented Talents Training Model of Material Formingand Control Engineering, Journal of Hunan Metallurgical Professional Technology College, Vol. 9 No.4, pp. 70-72, 2009

[2] Jitao Du. Analysis of Innovating Education methods for Advanced Vocational Colleges[C], 2011 International Conference on Education and Education Mangement, pp.215-219, 2011.

[3] Jitao Du. Consideration for Graduate Design Selecting Topics of Advanced Vocational Colledges[C], 2011 International Conference on Education and Education Mangement, pp. 220-223, 2011.
[4] Jitao Du. Jobs Analysis of Dies \& Mould Design Manufacturing Speciality For Shanghai, 2011 Interational Conference on Future Management Science and Engineering, Lecture Notes in Information Technology,Vol.5-6, pp.238-242, 2011.

[5] Jitao Du. Driving By Innovation Mechanical Speciality Teaching Mode Reformation [C], 2012 International Coference on Enigineering and Business Management, Shanghai. pp.37-40, 2012. 